\title{
Fabrication and Characterization of Biodegradable Polymer as Multifunction Finishing Agent for Natural Fabrics
}

\author{
Eman Osman \\ Textile Metrology Lab., National Institute for Standards, Egypt.
}

\begin{abstract}
TN THIS WORK, chitosan solution in aqueous acetic acid used to produce both bulk and nano sized chitosan as finishing agent for cotton and silk fabrics using different coating techniques; pad-dry-cure (for bulk chitosan) and electrospraying (for nano chitosan). The treated fabric samples were characterized via FTIR, XRD and SEM. The obtained coated samples were evaluated for their antibacterial activity towards both E. coli (Gram -ve) and S. aureus $(\mathrm{Gram}+\mathrm{ve})$ bacteria. Also, the treated samples were assessed for ultraviolet protection degree through measuring the ultraviolet protection factor (UPF). Moreover, the wettability of the treated samples was evaluated through measuring the contact angle of water droplet on the fabric surface. Additionally, the electrical conductance and capacitance of all treated samples were measured. The obtained nano coated chitosan fabrics have proved to be of high potential eco-friendly and cost-effective products to be used for hygiene, medical and electromagnetic shielding applications.
\end{abstract}

Keywords: Chitosan, Pad-dry-cure, Electrospraying, Antibacterial, Electric Conductance, Multifunction.

\section{Introduction}

Electrospinning has gained popularity in the last 10 years due to the increased interest in nanoscale properties and technologies. This technique allows for the production of polymer fibers with diameters varying from $3 \mathrm{~nm}$ to greater than 5 $\mu \mathrm{m}$ [1]. Electrospinning is a straightforward and versatile technique for fabrication of nanofibers from a variety of polymer solutions. Nanofibers with high surface area to volume ratio, high porosity and small fiber diameter make them ideal materials for biomedical applications [2].

Electrospraying is a process similar to electrospinning but is used when the viscosity of the liquid is sufficiently low. It is well known that viscosity of a polymer solution is the characteristic of intermolecular interactions between polymer chains. The high viscosity of chitosan solution is due to the strong hydrogen bonding between $\mathrm{NH}_{2}$ and $\mathrm{OH}$ groups of chitosan polymer chains [3]. The electric charge draws the liquid from the capillary nozzle in the form of a fine jet, which eventually disperses into droplets. The droplets produced by electrospraying are highly charged and can be smaller than $1 \mathrm{~mm}$. The size distribution of the droplets is usually narrow, with low standard deviation [4]. In electrospraying the size of the droplets can be controlled mainly by the liquid flow rate, and the droplet charge by adjusting the voltage applied to the nozzle. The charged aerosol is self dispersing, which prevents the droplets from coagulation [5].

Due to the environmental and toxicological concerns about the use of heavy metals for the production of NPs, researchers have been recently exploring the use of biopolymers such as chitosan in the antimicrobial finishing of textiles [6,7]. The existence of $-\mathrm{NH}_{2}$ groups on the chitosan backbone (Fig. 1) [8,9] provides several unique chemical and biological properties such as biocompatibility, antibacterial properties, heavy metal ion chelation ability, gel-forming properties and hydrophilicity [10-12 ]. However, the research on chitosan NPs for textile applications is limited because most of the literature is based on the use of bulk chitosan as a coating or finishing agent. Antimicrobial fabrics with nanocoated chitosan have proved to be a durable, cost-effective and eco-friendly process [13]. Some research has 
first method, the fabric samples were individually immersed and soaked in the prepared chitosan solution for 7 minutes under magnetic stirrer, followed by passing though a padding mangle to ensure complete pick up of the suspended material and remove the excess solution, this sequence is repeated three times for each sample to assure maximum amount of chitosan adhesion. Then the samples were dried in an oven at $150^{\circ} \mathrm{C}$ for 3 minutes then thermo-fixed at $100^{\circ} \mathrm{C}$ for 5 minutes. Used liquor ratio was 1:50.

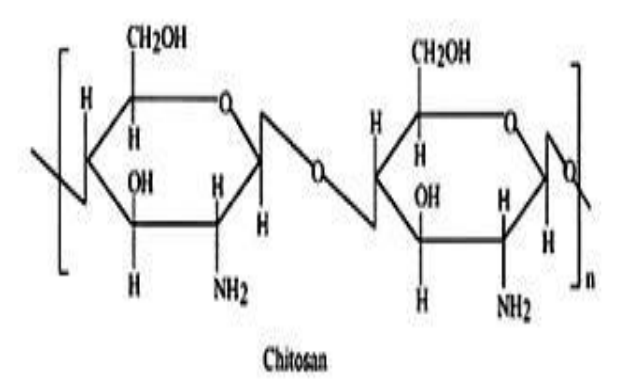

Fig. 1. Chemical structure of chitosan

In the second technique, the fabric samples were subjected to electrosprayed chitosan solution using Electrospinning instrument of model - NaBond- made in China. The polymer was pumped from $20 \mathrm{~mL}$ syringe into a needle gauge of $8 \mu \mathrm{m}$ inner diameter. A power supply voltage of $20 \mathrm{kV}$ was conducted to the solution. The distance between the tip and the collector was maintained as $12.5 \mathrm{~cm}$. The flow rate was set at $10 \mathrm{ml} / \mathrm{h}$ and spinning was performed for 2 hours. Aerosols were received on the fabrics surfaces suspended on a rotating cylinder collector.

\section{Testing and Analysis \\ Antibacterial Assessment}

Escherichia coli (E. coli) (Gram negative bacterium) and Staphylococcus aureus (S. aureus) (Gram positive bacterium), were used for estimation of antibacterial activities. Each kind of the used bacteria was colonized on agar medium. This medium was sterilized for $20 \mathrm{~min}$ at $121^{\circ} \mathrm{C}$ under pressure. Fresh inoculants for antibacterial assessment were prepared on agar nutrient at $37^{\circ} \mathrm{C}$ for 24 hours [18].

\section{Evaluation of ultraviolet Protection Degree}

UPF is actually the measure of UV radiation (UVA and UVB) blocked by the fabric. Higher UPF value means more blocked UV radiation [19]. The transmittance and UPF values of the shown, however, that chitosan NPs have a less inhibiting effect on some kinds of bacteria, while conversely, other researchers reported that chitosan NPs exhibit higher antibacterial activity due to the NP's larger surface area and higher affinity with bacteria cells, which yield a quantumsize effect [14-16]. These contradictory results suggest that the antimicrobial mode of action of chitosan is not a simple mechanism but needs further investigation. However, electrospinning of biopolymer solutions has proven to be difficult due their poly cationic nature, low chain flexibility opposing chain entanglement, and poor solubility in organic solvents [17].

Electrical conductivity of textile fabrics has gained great interest among researchers; because of the traditional fibers used in the textile fabrics are electrically insulating materials. So, adding some conductivity can bring new usage areas for textile fabrics, especially for health-related topics like antistatic and electromagnetic shielding [18]. Electroconductive textile fabrics can be obtained using several methods such as; chemical coating, metallization, electroless deposition, the insertion of metallic yarns, and the deposition of thin layers containing conductive fillers as carbon nanotubes and carbon black particles [19].

In this paper the traditional surface coating (pad-dry -cure) and electrospraying processes were tested as tools for the production of treated cotton and silk modified fabrics with respect to its application for medical, and electromagnetic shielding use. The suitability of the two main processes was investigated.

\section{Experimental}

\section{Materials and Chemicals}

The tests were carried out on pure silk and cotton fabric samples; where: silk is $69 \mathrm{~g} / \mathrm{m}^{2}$ in weight and $0.13 \mathrm{~cm}$ in thickness and cotton is 165 $\mathrm{g} / \mathrm{m}^{2}$ and $0.29 \mathrm{~cm}$ thickness.

All the used chemicals (low molecular weight chitosan, glacial acetic acid, and agar) were of laboratory grade chemicals.

\section{Methods}

$(2 \% \mathrm{w} / \mathrm{v})$ chitosan was dissolved in $10 \%$ acetic acid then shacked on magnetic stirrer for three hours before using.

\section{Fabric Treatment}

Each of silk and cotton fabric samples was modified with two different methods, i.e. pad-drycure and electrospraying method. Where, in the 
examined fabric samples were measured using a Varian (UV-VIS-NIR) spectrophotometer. The UPF value of the fabric therefore is determined from the total spectral transmittance all over the range. Whereas, the UV-B Transmittance was measured in the range $290-315 \mathrm{~nm}$, while the UV-A Transmittance was measured in the range $315-400 \mathrm{~nm}$.

\section{Fabric Wettability}

Contact angle measurements were carried out using video microscope (CVM) SDL- UK, with horizontal plate camera. The surface wettability was evaluated from the value of the contact angle measured with a drop of distilled water on the surface of the samples. The volume of the drops was maintained as $250 \mu \mathrm{L}[20,21]$. The reported angle is an average of 5 measurements on different areas of each sample.

\section{Electrical Conductance}

The conductance (nano Siemens/cm) and the capacitance (pico farad) of all treated fabric samples were measured using LCR meter, EUg8A- Agilent - USA. The applied frequency= $1 \mathrm{KHZ}$ and voltage level= $1 \mathrm{v}$ [22].

Fourier Transform Infrared Spectroscopy (FTIR)

FTIR spectra of the samples under test were recorded by means of a Nicolet 380 Spectrometer using a zinc selenid crystal, in the wavelength range 650- $4000 \mathrm{~cm}-1$. To ensure reproducible contact between the crystal face and the fabric, a pressure of approximately $18 \mathrm{Kpa}$ was applied to the crystal holder. The FTIR absorbance frequencies for the treated samples were recorded with an average of 28 scans by using a resolution of $4 \mathrm{~cm}^{-1}$.

\section{$X$-ray Diffraction (XRD)}

$X$-ray diffraction measurements of all the untreated and treated samples were carried out using aScintag (USA) Diffractometer of $\mathrm{Cu} \mathrm{k}$ radiation operated at $45 \mathrm{kv}, 40 \mathrm{~mA}$ at a wavelength $\lambda=154.6 \mathrm{~cm}^{-1}$. The diffractograms were recorded with diffraction angle $2 \theta$ ranging from 0 to $40^{\circ}$ with a scan rate $2 \%$ minute.

\section{Scanning Electron Microscopy (SEM)}

The Scanning Electron Microscope for all the tested samples were carried out using SEM Model Quanta 250 FEG (Field Emission Gun) attached with EDX Unit (Energy Dispersive X-ray Analyses) Netherlands, with accelerating voltage $30 \mathrm{KV}$, magnification $14 \mathrm{x}$ up to 1000000 and resolution for Gun.1n. A gold layer was deposited on the samples before analysis.

\section{Results and Discussion}

Antibacterial Assessment

The antibacterial activities of the uncoated and coated fabric samples against gram +ve and gram -ve bacteria are mentioned in Table 1. Regarding to the gram +ve bacteria (staphylococcus), it is observed that, the tested cotton samples show a gradual increase in their resistivity to the bacterial growth from poor, fair to good resistance which is the same behavior of the tested silk samples.

When considering the gram -ve bacteria (ecoli), it is observed that the tested cotton and silk samples show the same attitude towards the bacterial resistance, i.e. gradation from poor, good to very good resistance with the different treatments as shown in Table 1. Moreover, it is noticed that, the electrosprayed cotton and silk samples give a clear inhibition zone, i.e. meaning very good resistance towards the gram $-v e$ bacteria compared to the gram +ve bacteria.

Comparing the two treatment techniques used, it is clarified that, samples treated with chitosan using the electrospraying technique gave the best results than those of the samples treated with the pad-dry-cure method. This result may be explained according to the nano chitosan particles yielded from electrospraying which exhibit higher antibacterial activity due to the larger surface area and higher affinity with bacteria [23]. Additionally, the behavior of the treated and untreated fabrics towards the gram ve bacteria was better (more resistive) than their attitude towards the gram +ve bacteria. This could be due to the fact that, gram +ve bacteria have a thicker and more rigid peptidoglycan cell wall. Therefore, the antibacterial activity of treated samples with nano chitosan as an antibacterial biopolymer against gram + ve bacteria is less than gram -ve bacteria [24].

\section{UV Protection Degree}

UPF is actually the measure of UV radiation (UVA and UVB) blocked by the fabric. Higher UPF value means more blocked UV radiation. It is obvious from Table 2 that, UPF values of cotton samples are greater than those of silk samples whether treated or blank. This may be due to the fact that, UPF is strongly dependent on the chemical structure of the fibers where the nature of the fibers influences the UPFs as they vary in UV transparency [25]. Cotton fabric provides a higher UPF because the natural pigments, pectin, and waxes act as UV absorbers especially, the

Egypt. J. Chem. 61, No. 4 (2018) 
TABLE 1. The antimicrobial activity of the untreated and treated fabric samples towards gram +ve and gram -ve bacteria

\begin{tabular}{|c|c|c|c|c|c|c|}
\hline \multirow{2}{*}{ Bacteria } & \multicolumn{2}{|c|}{ Blank (untreated) } & \multicolumn{2}{c|}{$\begin{array}{c}\text { Pad-dry-cure } \\
\text { Treatment }\end{array}$} & \multicolumn{2}{c|}{$\begin{array}{c}\text { Electrospraying } \\
\text { Treatment }\end{array}$} \\
& \multicolumn{2}{|c|}{} & \multicolumn{2}{|c|}{ Silk } \\
\cline { 2 - 7 } & Cotton & Silk & Cotton & Silk & Cotton & good \\
\hline $\begin{array}{c}\text { Gram (+ve) } \\
\text { Staphilococcus }\end{array}$ & Poor & Poor & fair & fair & good & \\
\hline Gram (-ve) ecoli & Poor & Poor & good & good & Very good & Very good \\
\hline
\end{tabular}

TABLE 2. The UPF values of the untreated and treated cotton and silk samples

\begin{tabular}{|c|c|c|c|c|c|}
\hline \multicolumn{2}{|c|}{ Blank (untreated) } & \multicolumn{2}{c|}{$\begin{array}{c}\text { Eraditional Treatment } \\
\text { (Pad-Dry-Cure) }\end{array}$} \\
\hline Cotton & Silk & Cotton & Silk & Cotton & Silk \\
\hline 9.17 & 7.01 & 19.29 & 9.61 & 21.80 & 17.89 \\
\hline
\end{tabular}

tested samples are not bleached.

The UPF values of all the treated fabric samples are higher than those of the blank ones referring to more UV protection, i.e. for cotton it showed good protection (19.29 and 21.8) while silk offered poor to good UV protection degree after treatment (9.61 and 17.89). Also, the samples coated with nano chitosan using the electrospraying method had greater UV protection degree than those coated with the traditional paddry-cure method. This could be due to the higher surface area to volume ratio resulting from the electrospraying leading to UPF increase, since UPF is greatly affected by the fabric density, constitution and thickness [26].

\section{Contact Angle and Wettability Measurement}

The surface wettability of the untreated and treated fabric samples was evaluated from the values of the contact angle measured with a drop of distilled water on the surface of the samples. The obtained results are shown in Fig. 2. According to the results, the blank (untreated) cotton sample showed a contact angle less than $90^{\circ}$ which may be due to the presence of hydroxyl groups in the cellulose structure, so the water droplet spread on the fabric surface in a short time representing the hydrophilic nature of cotton fabric [23]. Chitosan coated cotton samples (either with pad-dry-cure or electrospraying) had a contact angles less than $90^{\circ}$ but still more than the contact angle of the uncoated sample. This means that, the surface hydrophilicity reduced due to the interaction between cellulose and chitosan polar groups. This is the same attitude of the tested silk samples, which showed decreasing in the hydrophilicity behavior after coating with chitosan. Although, the contact angle of both fabric samples coated with electropsprayed chitosan is larger than the contact angle of their corresponding samples using pad-dry-cure coating method, yet the silk fabric samples had lesser hydrophilicity than cotton samples as shown in Fig. 2. We can say that, chitosan acted as a hydrophobic layer on the surface of both fabrics; cotton and silk.

\section{Electrical Conductance}

The electrical conductivity of the textile fabrics has become an interesting issue in the last decade because of the numerous uses could be added to the fabric on adding this property. Electrical conductance is the ease with which an electric current passes, while capacitance is the ability of a body to store an electric charge. Any 


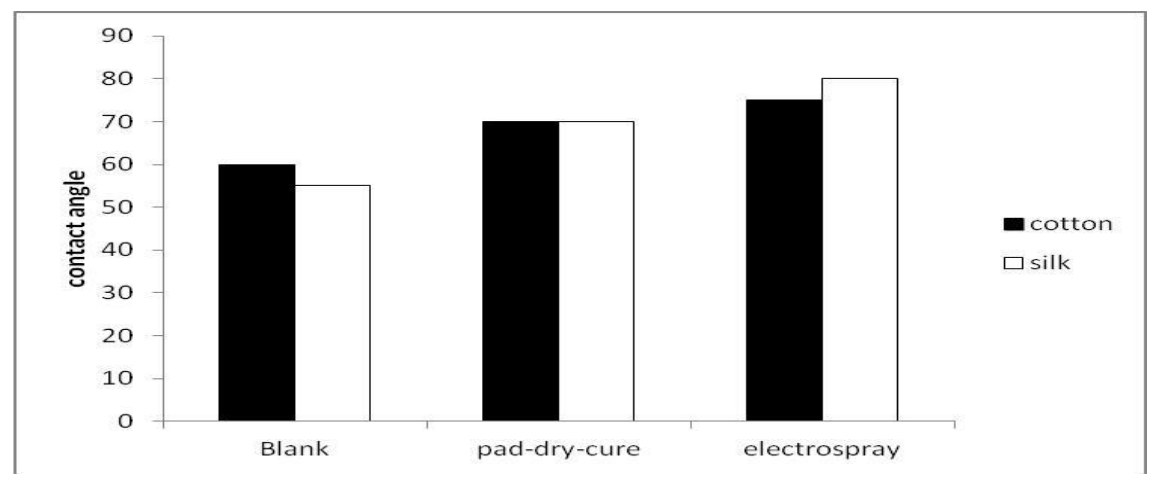

Fig. 2. Contact angle variation of the untreated and treated fabric samples

object that can be electrically charged exhibits self-capacitance [27-28]. Results listed in Table 3 show the variation in the conductance and capacitance between the untreated and treated fabric samples.

It is noticed that, the conductance of cotton samples increased with about $173 \%$ and $800 \%$ for traditionally coated and electrosprayed coated samples respectively, comparing to the untreated cotton ones. While the capacitance decreased with about $67 \%$ and $97 \%$ for both coating techniques. Moreover, the examined silk samples showed conductance increment of about 244\% and $777 \%$ for pad-dry-cure and electrospraying techniques respectively, comparing to those untreated silk samples. Nevertheless, the decrease in the capacitance of coated silk samples was around $91 \%$ and $63 \%$ for both coating techniques respectively. It is clear that, electrospraying coating technique produced highly conductive fabrics with decreasing their ability to store the electric charge (decreasing capacitance). So, the produced samples could be subjected to the electromagnetic shielding uses[29].

\section{FTIR Analysis}

The FTIR spectra of the uncoated and coated cotton and silk fabric samples using pad-dry-cure and electrospraying methods are presented in Fig. $3 \& 4$ respectively. The comparison of the spectra shows the evidence of typical peaks of chitosan as follows: around $3400 \mathrm{~cm}^{-1}$ assigned to $\mathrm{NH}$ and/or $\mathrm{OH}$ stretching vibration, at $\approx 2900 \mathrm{~cm}^{-1}$ due to $\mathrm{CH}_{3}$ symmetric stretching. Other typical peaks around $1640 \mathrm{~cm}^{-1}$ assigned to $\mathrm{C}=\mathrm{O}$ stretching vibration, $1440 \mathrm{~cm}^{-1} \mathrm{C}-\mathrm{N}$ stretching vibration, $\approx 1370 \mathrm{~cm}^{-1}$ $\mathrm{CH}_{3}$ bending vibration and $\approx 1160 \mathrm{~cm}-1$ assigned to $\mathrm{C}-\mathrm{O}-\mathrm{C}$ bending vibration [30]. While, peaks at $\approx 1515 \mathrm{~cm}^{-1}$ and $1068 \mathrm{~cm}^{-1}$ assigned to $\mathrm{NH}$ bending in amide group which are overlapped by those of silk fabric, due to the presence of the same amine and amide groups on both silk and chitosan [31].

These spectra of all the tested samples were very similar suggesting that the addition of chitosan had no effect on the positions of the characteristic peaks of both cotton and silk fabrics. This indicated that the chitosan was not chemically bound to the fabric but was physically adsorbed on the fabric surface and can only penetrate within the fibers [32].

$X R D$

X-ray diffraction data for polymers generally provide information about crystallinity, crystal size, orientation of the crystallites and phase composition in semi-crystalline polymers. The XRD pattern of all tested cotton and silk fabric samples showed several peaks. Cotton samples pattern revealed three peaks centered at $2 \theta \approx 14^{\circ}$, $16^{\circ}, 22^{\circ}$. All appeared peaks are broad except the fundamental one at $22^{\circ}$ which is sharp, meaning crystalline phase of the samples. On the other hand, silk samples patterns clarified peaks at $2 \theta \approx$ $19^{\circ}, 22^{\circ}$ and $25^{\circ}$. The fundamental peak of silk samples appeared at $2 \theta \approx 22^{\circ}$. The crystallinity index of the tested samples can be calculated from the equation [33]:

$\mathrm{CI}=(\mathrm{If}-\mathrm{Is} / \mathrm{If}) \times 100$

where, If: is the intensity of the fundamental peak and If: is the intensity of the secondary peak.

Also, the average particle size can be calculated using Debye-Scherrer formula:

$\mathrm{D}=0.9 \lambda / \beta \cos \theta$

where: $\lambda$ : is the wavelength of XRD $(1.541 \mathrm{~nm})$, $\beta$ : is the full width at half maximum (FWHM), $\theta$ : is the diffraction angle and D: is the particle size 


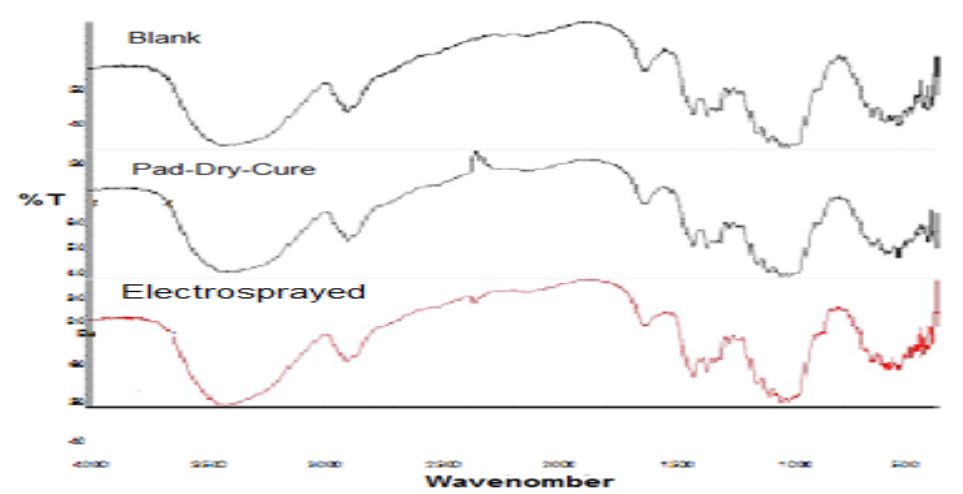

Fig. 3. The FTIR spectra of the uncoated and coated cotton fabric samples using pad-dry-cure and ectrospraying methods

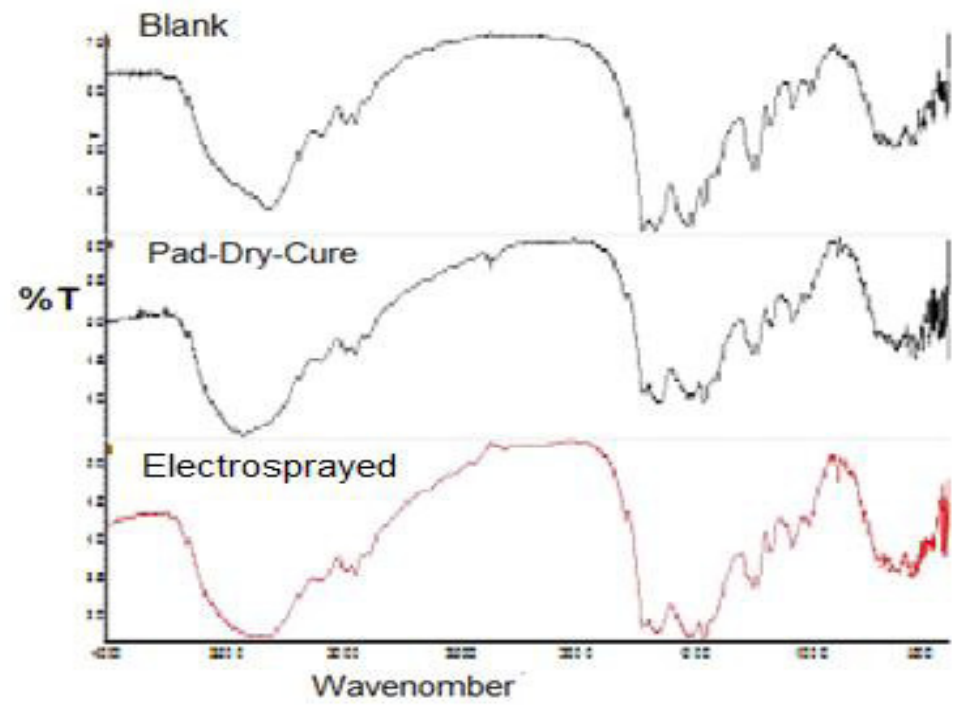

Fig. 4. The FTIR spectra of the uncoated and coated silk fabric samples using pad-dry-cure and electrospraying methods

TABLE 3. The change in electrical conductance and capacitance of the examined cotton and silk fabric samples

\begin{tabular}{|c|c|c|c|c|c|c|}
\hline \multirow{2}{*}{$\begin{array}{c}\text { Measured } \\
\text { parameter }\end{array}$} & \multicolumn{2}{|c|}{ Blank (untreated) } & \multicolumn{2}{c|}{$\begin{array}{c}\text { Pad-dry-cure } \\
\text { Treatment }\end{array}$} & \multicolumn{2}{c|}{$\begin{array}{c}\text { Electrospraying } \\
\text { Treatment }\end{array}$} \\
\cline { 2 - 7 } & Cotton & Silk & Cotton & Silk & Cotton & Silk \\
\hline Conductance (ns) & 150 & 24 & 259.5 & 59.9 & 1200 & 186.5 \\
\hline Capacitance (pf) & 386.7 & 286 & 261.3 & 248.7 & 375.2 & 182.5 \\
\hline
\end{tabular}

diameter.

From the obtained results listed in Table 4 it is clear that, the crystallinity/amorphousity ratio of the cotton samples increased after coating giving nearly comparable values. While, the crystallinity /amorphousity ratio of the silk samples increased after coating with electrosprayed nano with more than that after coating with bulk chitosan comparing to the untreated samples. This could be explained by the higher surface area to volume ration of electrosprayed nano chitosan having plenty of hydroxyl and amino groups which could form strong intermolecular hydrogen bonds, alongside with the higher porosity of the fabric molecules which efficiently enhance the regularity 
of the particles leading to increasing the crystallite regions $[34,35]$.

In considering the chitosan particle size calculated using equation (2) and listed values in Table 4, it is obvious that, the particle size of chitosan is minimized to the nano scale after electrospraying as a result of the used high voltage, which could affect all the investigated properties of the treated fabric samples as discussed above.

\section{SEM}

The possible changes of the surface morphology of the uncoated and coated fabric samples have been evaluated by scanning electron microscope (SEM). Comparing the SEM images (Fig. 5 a-h); there are morphological changes clearly obvious between uncoated (blank) and coated tested samples. It is obvious that, the untreated cotton and silk samples' surfaces are clean and smooth (Fig. 5a, 5e). While, the pad-dry cure treatment (Fig. 5b, 5f) offered a smooth homogeneous chitosan film layer coated the fibers surface in the bulk size. Regarding to the electrosprayed cotton samples (Fig. 5c, 5d) it is noticed that, chitosan turned into nano size forming a layer penetrated the intermolecular spaces between the fibers. When measuring chitosan particle size in this case it was found that the sizes in the nano scale larger than $100 \mathrm{~nm}$, this result agrees well with the previously reported chitosan works [36]. Discussing the electrosprayed silk samples (Fig. $5 \mathrm{~g}, 5 \mathrm{~h})$ we can see that, nano formed chitosan appear as granules on the sample surface, when magnifying the image we observed that the particle size of the electrosprayed chitosan is more than $100 \mathrm{~nm}$ as shown in Fig. 5h. This finding can be related to the fact that the flow rate and the voltage applied to the electrosprayed solution have a great effect on the particle size, i.e. there is a converse relationship between the particle size and flow rate [37].

\section{Conclusion}

The purpose of this study is to offer ecofriendly and economically multifunctional modified natural fabrics which can be used in several hygiene and medical applications. The goal of this research work was achieved by applying chitosan as a biodegradable eco-friendly finishing agent on both cotton and silk textile fabrics using two different application techniques, i.e. paddry-cure and electrospraying, then characterizing and evaluating the two techniques. The coated samples were evaluated for antibacterial activity against gram +ve and gram -ve bacteria, UV protection degree through evaluating UPF values and the wetting measurement by measuring the water contact angle on the fabric surface. Also, the electrical properties of the coated fabric samples were measured. All the tested samples were characterized via FTIR, XRD and SEM.

The obtained results depicted that; electrosprayed nano chitosan samples showed superior results over the examined pad-dry-cure coated samples for all investigated characteristics.

All these characteristic features revealed the high potential of electrosprayed nano chitosan as an eco-friendly, cost effective finishing agent for cotton and silk fabrics which can be subjected to several hygiene and/or biomedical uses. It is also found that, the nanosprayed treated samples work as a conductive fabric through coating treatment showing protection against static electricity charge and electromagnetic interference adding another application of the treated textile samples which can be subjected to the electromagnetic shielding applications.

TABLE 4. Variation of the crystallinity index and particle size with the variation of coating techniques

\begin{tabular}{|c|c|c|c|c|c|c|}
\hline & \multicolumn{2}{|c|}{ Blank (untreated) } & \multicolumn{2}{|c|}{$\begin{array}{c}\text { Traditional Treatment } \\
\text { (Pad-Dry-Cure) }\end{array}$} & \multicolumn{2}{|c|}{ Electrospraying } \\
\hline & Cotton & Silk & Cotton & Silk & Cotton & 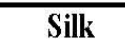 \\
\hline CI $(\%)$ & 65.6 & 23.8 & 78.9 & 27.6 & 78.7 & 29.7 \\
\hline Particle size & $\begin{array}{l}---- \\
\end{array}$ & ---- & $94.1 \mu \mathrm{m}$ & $93.2 \mu \mathrm{m}$ & $123 \mathrm{~nm}$ & $127 \mathrm{~nm}$ \\
\hline
\end{tabular}



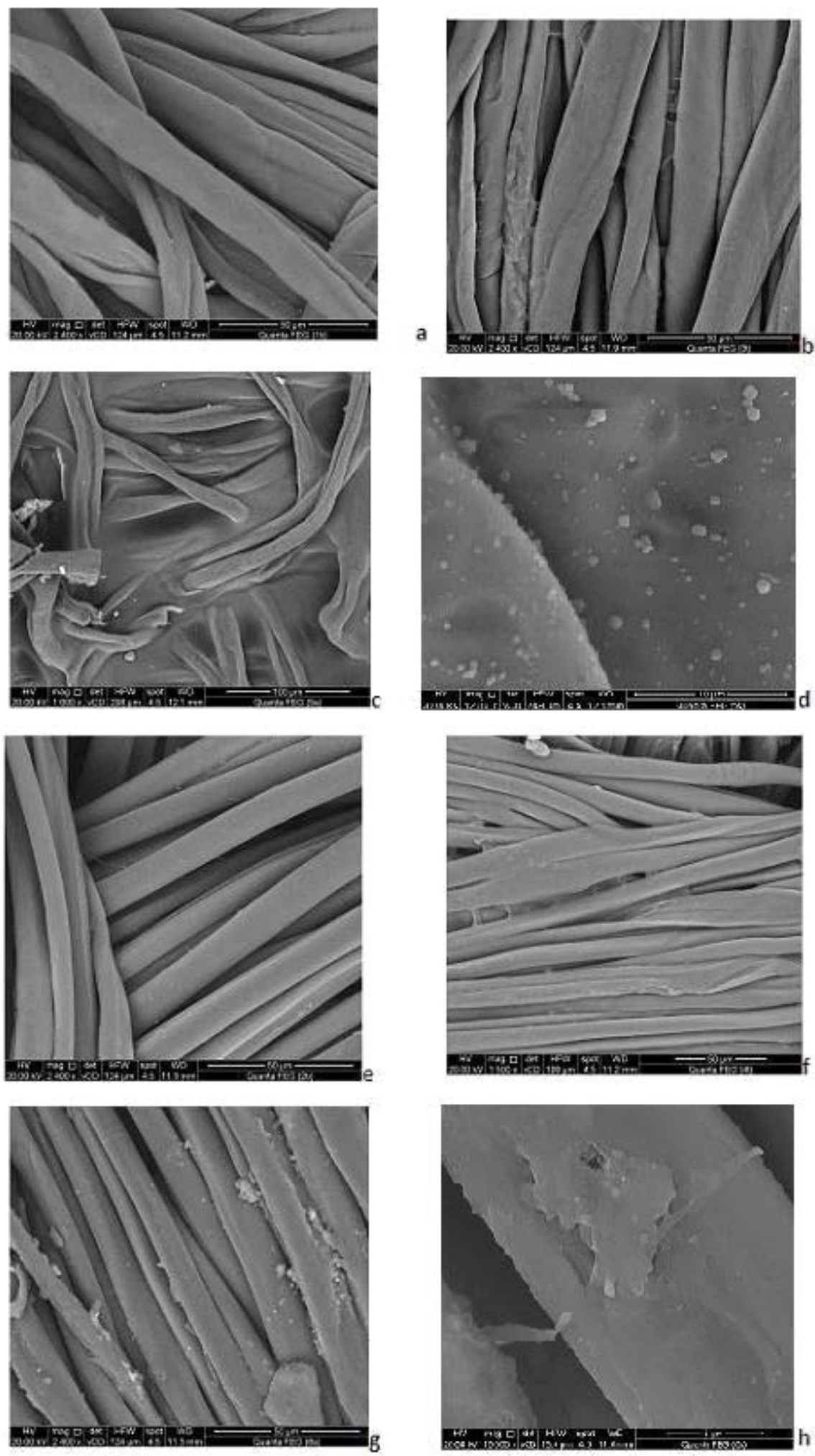

Fig. 5. SEM images of the tested untreated and treated samples, where: a) untreated cotton, b) pad-dry-cure cotton, c, d) electrosprayed cotton, e) untreated silk, f) pad-dry-cure silk and g) electrosprayed silk 


\section{References}

1.Pham Q.P., Sharma U. \& Mikos A. G., Electrospinning of Polymeric Nanofibers for Tissue Engineering Applications:.A Review, J. Tissue Eng., 12 (5), 5051 (2006).

2. Jacobs V., Patanaik A. \& Anandjiwala R. D., Electrospun Chitosan Nanofibre Membranes for Antimicrobial Application: Role of Electrospinning Processing Parameters, Eur.Cells Mater. J., 19 (1), 4 (2010).

3. Bhattarai N., Edmondson D., Veiseh, Matsen F. A. \& Zhang M., Electrospun chitosan-based nanofibers and their cellular compatibility, Biomater., 26 6176-6184 (2005).

4. Jaworek A., Micro- and Nanoparticle Production by Electrospraying, Powder Technol. J., 176 (1), 18-35 (2007).

5. Jaworek A., Krupa A., Lackowski M., Sobczyk A.T., Czech T., Ramakrishna S., Sundarrajan S. \& Pliszka D., Electrospinning and Electrospraying Techniques for Nanocomposite for Non-Woven Fabric Production, Fibers Text. East. Eur. J., 17 (4), 77-81 (2009).

6. Zhuang X. , Liu X. F. \& Li S. Y., Antibacterial Finishing of Tencel/Cotton Nonwoven Fabric Using Ag Nanoparticles-Chitosan Composite, Journal of Engineered Fibers and Fabrics, 7 (2), 24-29 (2012).

7. Kweon D. K., Song S. B. \& Park Y. Y., In Vivo Performance of Chitosan/Soy-Based Membranes as Wound-Dressing Devices for Acute Skin Wounds, Tissue Eng Part A. 2013 Apr; 19, 860-869 (7-8).

8. Di Y., Li Q. \& Zhuang X., Antibacterial Finishing of Tencel/Cotton Nonwoven Fabric Using Ag Nanoparticles-Chitosan Composite, J. Eng. Fiber. Fabr., 7 (2), 24-29 (2012).

9. Sun K. \& Li Z. H., Preparations, Properties and Applications of Chitosan Based Nanofibers Fabricated by Electrospinning, Express Polym. Lett., 5 (4), 342-361 (2011).

10. Park C. J., Clark S. G. \& Lichtensteiger C. A., Accelerated Wound Closure of Pressure Ulcers in Aged Mice by Chitosan Scaffolds With or Without bFGF, Acta Biomater, 5, 1926-1936 (2009).

11. Ueno H., Yamada H. \& Tanaka, Accelerating Effects of Chitosan for Healing at Early Phase of Experimental Open Wound in Dogs, Biomater, 20
(1), 1407-1414 (1999).

12. Wang W., Lin S.Q. and Xiao Y.C., Acceleration of Diabetic Wound Healing with Chitosan-Crosslinked Collagen Sponge Containing Recombinant Human Acidic Fibroblast Growth Factor in HealingImpaired STZ Diabetic Rats, Life Sci., 82 190-204 (2008).

13. Zille A., Almeida L., Amorim T., Carneiro N., Fátima Esteves M., Silva C. J. \& Pedro Souto A., Application of Nanotechnology in Antimicrobial Finishing of Biomedical Textiles, Mater. Res. Express, 1, 1-38 (2014).

14. Gao Y. \& Cranston R., Recent Advances in Antimicrobial Treatments of Textiles, Text. Res. J., 78 (1), 7860-72 (2008).

15. Moritz M. \& Geszke-Moritz M., The Newest Achievements in Synthesis, Immobilization and Practical Applications of Antibacterial Nanoparticles, Chem. Eng. J., 228, 228596-613 (2013).

16. Schiffman J. D. \& Schauer C. L, Review: Electrospinning of Biopolymer Nanofibers and Their Applications, Polym. Rev., 48 (2), 48317-52 (2008).

17. Kriegel C. , Kit K. M., McClements D. J. \& Weiss J., Influence of Surfactant Type and Concentration on Electrospinning of Chitosan-Poly(Ethylene Oxide) Blend Nanofibers, Food Biophysics, 4, 213 228 (2009).

18. Yeo S. Y., Lee H. J. \& Jeong S. H., Preparation of Nanocomposite Fibers for Permanent Antibacterial Effect, J. Mate. Sci., 38, 2143-2147 (2003).

19. Akgun M., Becerir B. \& Alpay H. R., Ultraviolet (UV) Protection of Textiles: A Review, Proceeding of The Intern. Sci. Conf., (GABROVO) 19-20 November (2010).

20. ASTM D724-99, Standard Test Method for Surface Wettability of Paper (Angle-of-Contact Method).

21. ASTM D5946-96, Standard Test Method for Corona-Treated Polymer Films Using Water Contact Angle Measurements.

22. Kausik B. \& Kothari V. K., Review Article: Measurement of Dielectric Properties of Textile Materials and Their Applications, Indian J of Fiber and Textile Research, 34, 191-199 (2009).

23. Kim S. S. \& Lee J., Antibacterial Activity of Polyacrylonitrile-Chitosan Electrospun Nanofibers, 
Carbohydrate Polymers, 102, 23-237 (2014).

24. Rouhani S. A., Hemmati N. N., \& Bashari A., Antibacterial Finishing of Cotton Fabric via the Chitosan/TPP Self-Assembled Nano Layers, Fiber. Polym., 15 (9), 1908-1914 (2014).

25. Achwal W. B., UV Protection by Textiles, Colourage, 4, 50-51 (2000).

26. Mongkholrattanasit R., Cholachatpinyo A, Tubtimthai N. \& Rungruangkitkrai N., Evaluation of UV Protection Imparted by Wool Fabric Dyed with Natural Dye from Eucalyptus Leaf, Chiang Mai J. Sci., 41, 5.2 1208-1219 (2014).

27. Li B., Shan C. L., Zhou Q., Fang Y., Wang Y. L., Xu F., Han L. R., Ibrahim M., Guo, L. B., Xie G. L. \& Sun G., Synthesis, Characterization, and Antibacterial Activity of Cross-Linked ChitosanGlutaraldehyde, Mar. Drugs, 11, 1534-1552 (2013).

28. Charn L. N. \& Mamun B. I., Characterization of Textile-Insulated Capacitive Biosensors, Sensors (Basel), 17 (3), 574 (2017).

29. Das A., Kothari V. K., Kothari A., Kothari A. \& Kumar A., Effect of Various Parameters on Electromagnetic Shielding Effectiveness of Textile Fabrics, Indian. J. Fibre. Text. 34, 144-48 (2009).

30. Periolattoa M., Ferrero F. \& Vineis C., Antimicrobial Chitosan Finish of Cotton and Silk Fabrics by UVCuring With 2-hydroxy-2-methylphenylpropane-1one, Carbohydr. Polym., 88, 201-205 (2012).

31. Pakravan L. M., Production of Chitosan-Based Non-Woven Membranes Using The Electrospinning Process, Presentee en Vue De L'obtention du diplomed de Philo Ophiae Doctor, Juillet (2012).
32. John R. \& Sasi F. S., Structural and Morphological Studies of Bean-Like ZnS Nanostructures by Aqueous Chemical, Chalcogenides Lett., 7 (4), 269-273 (2010).

33. Ericka N., Johnson F., Sharathkumar K. M., Shelby F. T., James W. R., X-ray Diffraction of Cotton Treated with Neutralized Vegetable Oilbased Macromolecular Crosslinkers, Journal of Engineered Fibers and Fabrics, 5 (1), 10-20 (2010).

34. Tripathi S., Mehrotra G.K. \& Dutta P. K., Physicochemical and Bioactivity of CrossLinked Chitosan-PVA Film for Food Packaging Applications, Int. J. Biol. Macromolecules, 45, 372-376 (2009).

35. Saita K., Nagaoka S., Shirosaki T., Horikawa M., Matsuda S. \& Ihara H., Preparation and Characterization of Dispersible Chitosan Particles With Borate Crosslinking and Their Antimicrobial and Antifungal Activity, Carbohydr. Res., 349, 52-58 (2012).

36. Guo D. Z., Rui S., Shi L. N. \& Qiang X., Development and Characterization of a Novel Chitosan-Coated Antioxidant Liposome Containing Both Coenzyme Q10 and Alpha-Lipoic Acid, J. Microencapsul, Early Online, 1-9 (2014).

37. Zhao L. M., Shi L. E., Zhang Z. L., Chen J. M., Shi D. D., Yang J. \& Tang Z. X., Preparation and application of Chitosan Nanoparticles and Nanofibers, Brazilian J. Chem. Eng., 28 (3), 353362 (2011).

(Received 14 /3/2018; accepted 7/6/2018) 


\title{
تصنيع وتوصيف بوليمر قابل للتحلل بيئيا كمادة تجهيز مقاوم للبكتيريا للاقمشة الطبيعية

\begin{abstract}
ان الكيتوز ان من اكثر و المن البوليمر ات القابلة للتحلل من حيث الاستخدام كمادة تجهيز للاقششة وخصوصا الطبيعية منها

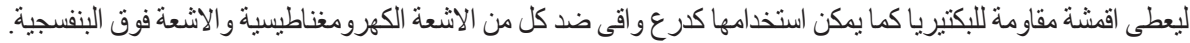

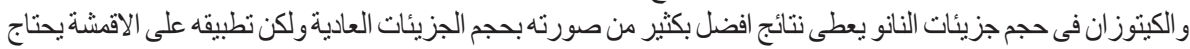

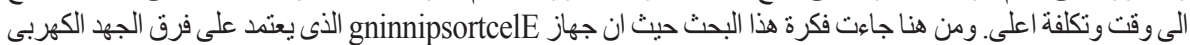

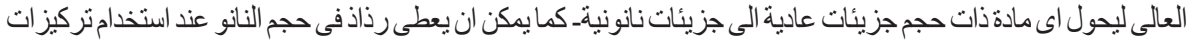

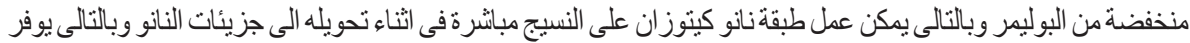
فى الوقت و التكلفة ويعطى نتائج افضل. ومن هنا كان جاءت فئرة فئرة هذا البحث.

تم استخداد تركيزة و احد من الكيتوز ان المذاب في حمض الخليكو وتطبيق هذا المحلول على نو عين من الاقمشة الطبيعية (القطن

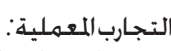
و الحرير) بطريقيتين مختلفتين:
\end{abstract}

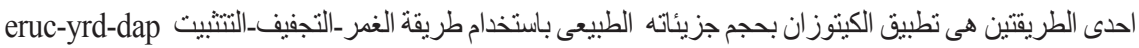

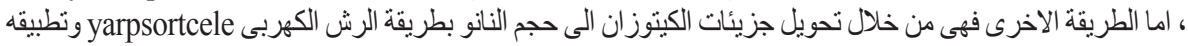

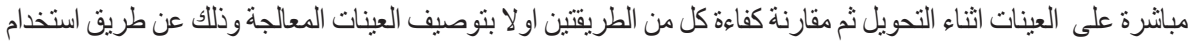

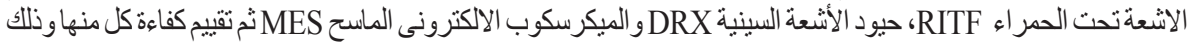

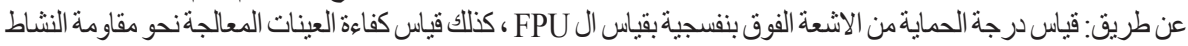

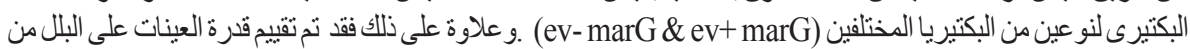

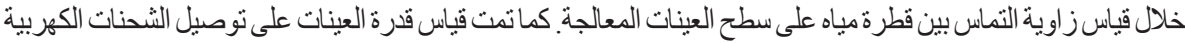

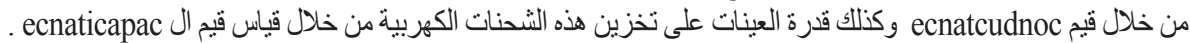
و اخير ا فقد تمت مقارنة نتائج طريقتى التطبيق المختلفتين لكل العينات التى تم تحضبير ها لتحديد كفاءة كل طريقة.

$$
\text { اوضمحت النتائج: النتج التى حصلناعليها ان : }
$$

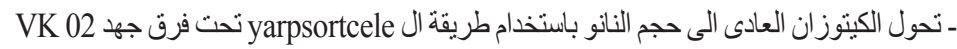
ـ تفوق طريقة تطبيق النانو كيتوز ان بالرش الكهربى gniyarpsortcele على الطريقة التقليدية eruc-yrd-dap فى كل من عينات القطن و الحرير التى تم اختبار هان النهان ـ مقاومة الاقمشة المعالجة بالنانو كيتوز ان للبكتريا (ev-marg) اكثر من تلك العينات المعالجة نحو مقاومتهالل (ev+ marg) ـ يعمل الكيتوزان كطبقة مقاو مة للمباه عند استخدامه فى التطبيق على الاقمشة الطبيعية مما يؤدى الى ارتفاع قيمة زاوية التماس بين قطرة المياه وسطح القماش المعالج

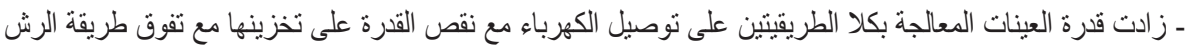

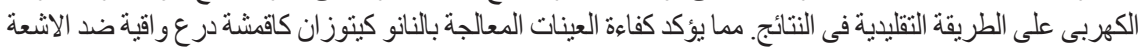

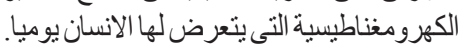

$$
\text { - تم تأكيد كل النتائج التى حصلنا عليها من خلال تصوير العينات بالميكرسكوب الالكترونى الماسح }
$$

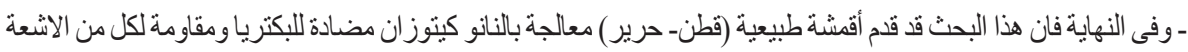

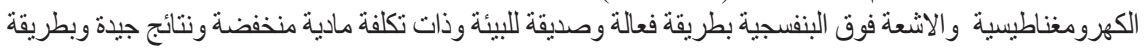

